\title{
Threats to Health and Well-Being Perceived by Older \\ People in Poland and Portugal
}

\section{Ameaças à Saúde e ao Bem-Estar Percebidas pelos Idosos em Portugal e na Polónia}

\author{
Maria Piedade BRANDÃO $\rrbracket^{1,2}$, Laura MARTINS ${ }^{3}$, Marlena SZEWCZYCZAK ${ }^{4}$, Dorota TALARSKA4, Ian PHILP5, \\ Margarida Fonseca CARDOSO 6,7 \\ Acta Med Port 2018 Jul-Aug;31(7-8):409-415 h https://doi.org/10.20344/amp.9613
}

\section{ABSTRACT}

Introduction: According to the OECD, Portugal and Poland rank below average in several well-being measures such as income and wealth, and health status. Investigating how people perceive the threats to health in these two countries, is an important issue to address priority needs. To meet this need, the objective of this paper was to compare the perceptions of the threats to the health and well-being among the Polish and Portuguese older persons and explore differences between the countries in respect of patterns of self-rated health.

Material and Methods: A Cross-sectional study with two convenience samples from primary health care services of Poland and Portugal was conducted; 480 adults aged 65 and over (247 Portuguese) were included. The EASYCare standard assessment of 2010 was applied under a joint project of both countries. The association between 'self-rated unhealthy' and socio-demographic and threats to health variables was examined using logistic regression.

Results: In both countries about two thirds of the older persons self-rated their health as unhealthy. Having more than enough finances was associated with a significant lower odds of being unhealthy compared with those without enough finances at the end of the month (Portugal: $\mathrm{OR}=0.25,95 \% \mathrm{Cl} 0.10$ to 0.63 ; Poland: $\mathrm{OR}=0.33,95 \% \mathrm{Cl} 0.12$ to 0.88 ). Visual problems, bodily pain, memory loss, feeling bored or lonely and reporting shortness of breath during normal activities was consistently associated with fair or poor self-rated health. Discussion: These findings provide important information regarding the health profile of older people which can help in the development of people-centred health systems where their lives and well-being can be improved.

Conclusion: The unhealthy perception of older people was consistently associated with indicators of major health threats.

Keywords: Aged; Aging; Health Status; Poland; Portugal

\section{RESUMO}

Introdução: De acordo com a Organização para a Cooperação e Desenvolvimento Económico, Portugal e Polónia ficam abaixo da média em várias medidas de bem-estar, como renda e riqueza, e estado de saúde. Investigar como as pessoas percecionam as ameaças à saúde nesses dois países, é uma questão importante para atender a necessidades prioritárias sentidas. Para atender a essa necessidade, o objetivo deste trabalho é comparar as perceções das ameaças à saúde e ao bem-estar entre as pessoas idosas polacas e portuguesas e explorar as diferenças entre os países, no que respeita aos padrões da auto-perceção do estado de saúde. Material e Métodos: Foi realizado um estudo transversal com duas amostras de conveniência nos Cuidados de Saúde Primários na Polónia e em Portugal; foram incluídos 480 adultos com 65 anos ou mais (247 portugueses). A avaliação padrão EASYCare de 2010 foi aplicada no âmbito de um projeto conjunto em ambos os países. A associação entre 'perceção não saudável' e as variáveis sociodemográficas e ameaças à saúde foi examinada através da regressão logística.

Resultados: Em ambos os países cerca de dois terços das pessoas idosas avaliaram a sua saúde como não saudável. O fato de ter finanças mais do que suficientes produziu uma menor probabilidade de não ser saudável em comparação com aqueles cujas finanças não eram suficientes no final do mês (Portugal: $O R=0,25$, IC 95\%: 0,10 a 0,63; Polónia: OR = 0,33; IC 95\%: 0,12 a 0,88). Problemas visuais, dor corporal, perda de memória, sentir-se aborrecido ou solitário e trefrir dificuladade respiratória durante as atividades normais foi consistentemente associado com uma saúde autoavaliada razoável ou insatisfatória.

Discussão: Estes resultados fornecem informações importantes sobre o perfil de saúde de pessoas idosas, o que poderá ajudar no desenvolvimento de sistemas de saúde centrados nas pessoas em que as suas vidas e bem-estar possam ser melhorados.

Conclusão: A perceção não saudável das pessoas mais velhas apresentou-se consistentemente associada a indicadores de principais ameaças para a saúde.

Palavras-chave: Envelhecimento; Estado de Saúde; Idoso; Polónia; Portugal

\section{INTRODUCTION}

With the demographic changes a considerable increase in the older population worldwide is taking place. This transition occurs differently in developed and developing countries. ${ }^{1}$ In the first, this increase was mainly due to improvement in quality of life and strengthening ${ }^{2}$ of health services, while in the second was mainly due to the technological innovations which have enabled the prevention and cure of previously fatal diseases. ${ }^{3,4}$ In Europe, there

\footnotetext{
1. ESSUA - Health School. University of Aveiro. Aveiro. Portugal.

2. CINTESIS - Center for Health Technology and Services Research. University of Porto. Porto. Portugal

3. University of Aveiro. Aveiro. Portugal.

4. Department of Preventive Medicine. Poznan University of Medical Sciences. Poznań. Poland.

5. Health Sciences. Warwick University. Coventry. United Kingdom.

6. Department of Population Studies. Instituto de Ciências Biomédicas de Abel Salazar. University of Porto. Porto. Portugal.

7. CIIMAR - Interdisciplinary Centre of Marine and Environmental Research. University of Porto. Porto. Portugal.

$\square$ Autor correspondente: Maria Piedade Brandão. mpiedade@ua.pt

Recebido: 29 de agosto de 2017 - Aceite: 06 de julho de 2018 | Copyright @ Ordem dos Médicos 2018
} 
has been a growing increase in the older population and consequently an increasing number of people needing some kind of help and care, including medical and hospital care..$^{1,5}$

With the growing number of older people we must give more attention to this specific population and find solutions that contribute to the wellbeing of the societies they live in. This is especially important in the regions which had endured regimes over a long period, as Poland and Portugal. One is from Central Europe and the other from Southern Europe, and both countries are members of the European Union. Poland is one of the most successful examples of transition from a communist regime to democracy throughout Central and Eastern Europe, that despite the immense difficulties - in a war-torn country - has managed to reduce illiteracy substantially in the early fifties of the last century. As a result of political changes, among other things every Polish citizen has equal access to health care services, which are financed from public funds. ${ }^{6}$ Portugal, from the Democracy deployment in April 25, 1974 to the present day, has changed in many areas of society. Regarding the field of education, the illiteracy has declined much considerably, but the older population still suffers from the consequences of a dictatorship where not all children and young people had access to education, and only the elite had access to higher education. Only after 1974 was free and compulsory education instituted. As a result, in 2015 about $25 \%$ of the population older than 65 had no education and only about half had primary education. ${ }^{7}$ One of the main changes brought about by the arrival of democracy was that health support is guaranteed for all. In 1979 the National Health Service was established as a universal, tax financed system. ${ }^{8}$

According to information obtained by OECD, people aged 65 and over in 2015 represented $20.5 \%$ of the Portuguese population ${ }^{7}$ while in Poland represented $15.6 \%{ }^{9}$ Life expectancy at birth in Portugal is almost 81 years, four years higher than in Poland. In terms of Education, in Portugal, $43 \%$ of adults aged $25-64$ have completed at least upper secondary education, much lower than in Poland with an average of $91 \%$. Portugal performs well (above OECD average) in measures of well-being in housing, personal security and environmental quality, while Poland performs well in personal security and in education and skills, but both countries rank below average in several well-being measures such as income and wealth, and health status. Generally, both Polish and Portuguese are less satisfied with their lives than the OECD average. In both countries about $15 \%$ of people believe that they do not have anyone they could rely on.

Functional independence and well-being are crucial for autonomous living of older people, and deficits contribute to an increase of hospital admissions and to the need for more healthcare. ${ }^{10-12}$ Although functional dependence is one of the greatest threats to health, it turns out that much unexplained heterogeneity exists between individuals. Also, trajectories of functional decline are difficult to predict from possible predictors such as the level of threats to health or multimorbidity. ${ }^{13}$

Self-assessment, or self-perception, of health and dependence by older people has been shown to have a predictive power in various events such as hospitalization, mortality and functional decline. ${ }^{14-17}$ The different environments of living and access to health and social care, as well as to leisure and socialization activities are relevant in terms of the older people's well-being and quality of life..$^{15}$ With aging, many threats to health occur, particularly at the level of the sensory functions of hearing and vision, ${ }^{18,19}$ that may contribute to functional decline, ${ }^{20,21}$ socialization decline and as a consequence loneliness ${ }^{22-24}$ and falls, the latter one of the major threats to health due to loss of functional capacity. ${ }^{20,25}$ In Europe scientific evidence has showed that one third of the people over 65 years old living at home suffer falls every year ${ }^{26-28}$, with Portugal suffering the same problem. ${ }^{29}$

The loneliness and decline in socialization constitute also health threats, contributing to the decline in well-being. Scientific evidence has shown that sleep problems ${ }^{30}$ and loss of memory are some of the consequences of social isolation. ${ }^{31,32}$ All these aspects have been documented in the literature as precursors of mental health decline especially among older people. ${ }^{24,33}$ Moreover, body pain has been reported as one of the greatest threats to health and is related to some mental disorders, especially those related from the change in emotional functions (e.g. joy and sorrow). ${ }^{34}$

EASYCare is an assessment instrument that helps health workers and informal caregivers assessing the health and care needs of older people. Originally developed as a World Health Organisation (WHO) project, EASYCare is used today in more than 40 countries involving all World Health Organization's regions. The EASYCare standard assessment of 2010 covers 49 threats to health, independence and well-being across seven domains: communication; self-care; mobility, safe, and relationships; accommodation and finance; health status; mental health and well-being.

In Portugal and Poland, EASYCare has a network of members with common interests and concerns about how older people understand their needs and live their lives. Furthermore, Poland and Portugal, as part of the international EASYCare network, contribute as examples of European cultures, with their differences and their similarities, suitable to study the perceptions of the elders in Europe.

Portugal and Poland have been using the EASYCare standard assessment for assessing the needs, priorities and threats to health of older persons for several years and recently, this instrument was validated for both countries. . $^{35,36}$ However there have been no studies evaluating and comparing both countries in terms of threats to health and well-being. Despite functional dependence being a crucial factor for aging well, fairly little is known about health threats in advanced age, particularly low purchasing power, 
low educational attainment, visual impairment, bodily pain, memory loss, feeling bored or lonely and reporting shortness of breath during normal activities. The opportunity to undertake this comparison is presented because both countries have been using the same approach in similar settings namely using data from individuals attending Primary Health Care (PHC) centres. Knowing the health threats of older persons at present will contribute to the definition of appropriate strategies by health services and to the mobilization of social responses and persons (family and communities) towards a sustainable health with less cost for individuals in particular and in countries in general. ${ }^{37,38}$

The authors of this study, wanted to compare and analyze the health threats of people born within the authoritarian regime in Poland and Portugal, taking into account these adverse backgrounds. Also, the authors wanted to show the potential of a simple instrument (EASYCare) in the context of primary health care, in recognizing health threats, in a generation with specific challenges posed by the ageing irrespective of the country where it is applied.

Because there are no known studies comparing and reporting health perceptions in European countries based in EASYCare and thus providing more insight into ageing in Europe, the aim of this study was to compare the perceptions of the threats to the health and well-being among Polish and Portuguese older persons, as well as exploring the relationships of health threats with the selfperception of health.

\section{MATERIAL AND METHODS \\ Instrument}

The EASYCare (Elderly Assessment System for Care) detailed elsewhere, ${ }^{15,39,40}$ is an assessment tool for older people, which seeks to assess the threats to the health, independence and well-being of the older person. After some modifications in the EASY-Care Standard, the last version designated in this study as the EASYCare-2010, has been used in many countries worldwide, ${ }^{14,15,17,41,42}$ and was validated in Portugal and Poland. ${ }^{35-36}$ It covers 49 items, including a summary global measure of self-rated health using a 5-point scale with response options 'excellent', 'very good', 'good', 'fair' and 'poor'. The first three response options were collated into the category 'self-rated healthy' and the other two options into the category 'self-rated unhealthy'. The 'healthy' (excellent, very good or good) and 'unhealthy' (fair or poor) groups were compared. The present research considered the fourteen EASYCare items that reflect threats to health and self perception of health.

\section{Data collection}

The data of this study came from two data collection sites, Central Europe (Poland) and Southern Europe (Portugal). Data collection was performed by master students and $\mathrm{PhD}$ students of the scientific area of Gerontology under the coordination of the Aveiro University (Portugal) and the University of Medical Sciences, Department of Preventive Medicine (Poland). All interviewers received training in the standardized use of the questionnaire. The interviewers explained the study to potential participants and invited them to participate.

\section{Participants}

Participants were selected from primary health care $(\mathrm{PHC})$ services in both countries. Globally the inclusion criteria were: adults aged 65 and over and without dementia, psychosis or mental retardation as reported by their physician. A total of 480 older adults, including 233 Polish (51 males) and 247 Portuguese (114 males) participated in this study. The convenience sampling method was employed in both countries where a consent form was obtained from each participant prior to the participation in the study. In Portugal the study was approved by the Ethics Committee of the Central Regional Health Administration (ARS) (Coimbra, Portugal) with the local code 006386 on $12^{\text {th }}$ March, 2013. In Poland the study was approved by the Ethics Committee of the Poznan University of Medical Sciences with the local code $526 / 13$ on $13^{\text {th }}$ June, 2013. The data was collected between May of 2013 and July of 2014.

\section{Statistical analysis}

Differences between means were tested using the independent $t$ test, and differences in frequencies were tested using Pearson Chi-square test, after ensuring the necessary assumptions were checked. Logistic regression analysis was used to identify the association between various variables and 'self-rated unhealthy'. Odds ratios $(\mathrm{OR})$ and $95 \%$ confidence intervals $(95 \% \mathrm{Cl})$ adjusted for age, sex, marital status and finances were calculated for each variable. OR greater than one was associated with increased odds of self-rating as "unhealthy".

All analyses were performed using the statistical software package PASW (SPSS) for Windows, version 24.0. For all tests, a 2-tailed significance level of 0.05 was used.

\section{RESULTS}

The majority of the participants rated their health as fair or poor $(69.2 \%$ of the 247 Portuguese participants, $66.5 \%$ of the 233 Polish participants). Since the sociodemographic profile differed between the two countries, and the two analyzed countries were from different regions of Europe with different cultural, social and political contexts, the comparison between the self-rated 'healthy' (excellent, very good or good) and 'unhealthy' (fair or poor) groups was performed separately for each country. The self-rated 'healthy' and 'unhealthy' groups were compared in terms of socio-demographic characteristics and threats to health identified with EASYCare (Table 1).

The mean age difference between the groups was less than five years in both countries. In Portugal, gender and marital status were associated with self-rated health $(p \leq$ 0.012). Female participants were more likely to self-rate their health as fair or poor $(\mathrm{OR}=2.32,95 \% \mathrm{Cl} 1.34$ to 4.04$)$, 
Table 1 - Comparison of socio-demographic variables and threats to health identified with EASYCare, between older people self-rated "healthy" and "unhealthy" in two European countries

\begin{tabular}{|c|c|c|c|c|c|c|c|c|c|c|}
\hline \multirow{3}{*}{$\begin{array}{l}\text { Characteristic } \\
\text { Age mean } \pm \text { SD }\end{array}$} & \multicolumn{4}{|c|}{ Portugal } & \multicolumn{6}{|c|}{ Poland } \\
\hline & \multicolumn{2}{|c|}{$\begin{array}{l}\text { Healthy } \\
(n=76)\end{array}$} & \multicolumn{2}{|c|}{$\begin{array}{l}\text { Unhealthy } \\
(n=171)\end{array}$} & \multirow{2}{*}{$\begin{array}{c}p \text {-value } \\
0.122\end{array}$} & \multicolumn{2}{|c|}{$\begin{array}{l}\text { Healthy } \\
(n=78)\end{array}$} & \multicolumn{2}{|c|}{$\begin{array}{l}\text { Unhealthy } \\
(n=155)\end{array}$} & \multirow{2}{*}{$\begin{array}{l}p \text {-value } \\
0.005\end{array}$} \\
\hline & 75.3 & \pm 8.1 & 77.0 & \pm 7.4 & & 74.5 & \pm 7.5 & 77.6 & \pm 8.4 & \\
\hline & $\mathrm{n}$ & $\%$ & $\mathrm{n}$ & $\%$ & & $\mathrm{n}$ & $\%$ & $\mathrm{n}$ & $\%$ & \\
\hline Female & 30 & $39.5 \%$ & 103 & $60.2 \%$ & 0.004 & 60 & $76.9 \%$ & 122 & $78.7 \%$ & 0.886 \\
\hline Marital status & & & & & 0.012 & & & & & 0.336 \\
\hline Married & 51 & $67.1 \%$ & 89 & $52.0 \%$ & & 40 & $51.3 \%$ & 68 & $43.9 \%$ & \\
\hline Single/ divorced & 9 & $11.8 \%$ & 13 & $7.6 \%$ & & 20 & $25.6 \%$ & 37 & $23.9 \%$ & \\
\hline Widowed & 16 & $21.1 \%$ & 69 & $40.4 \%$ & & 18 & $23.1 \%$ & 50 & $32.3 \%$ & \\
\hline Years of Formal Education & & & & & n.a. & & & & & 0.007 \\
\hline None & 11 & $14.5 \%$ & 30 & $17.5 \%$ & & 0 & $0.0 \%$ & 0 & $0.0 \%$ & \\
\hline 1 - 4 years & 50 & $65.8 \%$ & 123 & $71.9 \%$ & & 4 & $5.1 \%$ & 4 & $2.6 \%$ & \\
\hline $5-12$ years & 13 & $17.1 \%$ & 15 & $8.8 \%$ & & 54 & $69.2 \%$ & 134 & $86.5 \%$ & \\
\hline$>12$ years & 2 & $2.6 \%$ & 3 & $1.8 \%$ & & 20 & $25.6 \%$ & 17 & $11.0 \%$ & \\
\hline Income at the end of the month & & & & & 0.007 & & & & & 0.010 \\
\hline Not enough & 11 & $14.5 \%$ & 42 & $24.6 \%$ & & 6 & $7.7 \%$ & 23 & $14.8 \%$ & \\
\hline Just enough & 46 & $60.5 \%$ & 111 & $64.9 \%$ & & 29 & $37.2 \%$ & 78 & $50.3 \%$ & \\
\hline More than enough & 19 & $25.0 \%$ & 18 & $10.5 \%$ & & 43 & $55.1 \%$ & 54 & $34.8 \%$ & \\
\hline \multicolumn{11}{|l|}{ Difficulties } \\
\hline Seeing & 33 & $43.4 \%$ & 112 & $65.5 \%$ & 0.002 & 13 & $16.7 \%$ & 71 & $45.8 \%$ & $<0.001$ \\
\hline Hearing & 35 & $46.1 \%$ & 78 & $45.6 \%$ & 1.000 & 19 & $24.4 \%$ & 68 & $43.9 \%$ & 0.006 \\
\hline Using the bath or shower & 10 & $13.2 \%$ & 44 & $25.7 \%$ & 0.041 & 6 & $7.7 \%$ & 53 & $34.2 \%$ & $<0.001$ \\
\hline Problems with mouth or teeth & 19 & $25.0 \%$ & 49 & $28.7 \%$ & 0.660 & 15 & $19.2 \%$ & 46 & $29.7 \%$ & 0.120 \\
\hline Incontinence of urine & 15 & $19.7 \%$ & 48 & $28.1 \%$ & 0.219 & 23 & $29.5 \%$ & 85 & $54.8 \%$ & $<0.001$ \\
\hline Falls in the last twelve months & 16 & $21.1 \%$ & 56 & $32.7 \%$ & 0.086 & 22 & $28.2 \%$ & 58 & $37.4 \%$ & 0.211 \\
\hline $\begin{array}{l}\text { Get out of breath during normal } \\
\text { activities }\end{array}$ & 14 & $18.4 \%$ & 74 & $43.3 \%$ & $<0.001$ & 26 & $33.3 \%$ & 108 & $69.7 \%$ & $<0.001$ \\
\hline $\begin{array}{l}\text { Unable to pursue leisure } \\
\text { interests, hobbies, work and } \\
\text { learning activities }\end{array}$ & 1 & $1.3 \%$ & 23 & $13.5 \%$ & 0.006 & 19 & $24.4 \%$ & 89 & $57.4 \%$ & $<0.001$ \\
\hline Feeling lonely & 40 & $52.6 \%$ & 123 & $71.9 \%$ & 0.005 & 29 & $37.2 \%$ & 93 & $60.0 \%$ & 0.002 \\
\hline Trouble sleeping & 57 & $75.0 \%$ & 107 & $62.6 \%$ & 0.078 & 44 & $56.4 \%$ & 109 & $70.3 \%$ & 0.049 \\
\hline Bodily pain & 35 & $46.1 \%$ & 152 & $88.9 \%$ & $<0.001$ & 49 & $62.8 \%$ & 130 & $83.9 \%$ & 0.001 \\
\hline $\begin{array}{l}\text { Feelings of depression and } \\
\text { helplessness }\end{array}$ & 17 & $22.4 \%$ & 68 & $39.8 \%$ & 0.012 & 11 & $14.1 \%$ & 53 & $34.2 \%$ & 0.002 \\
\hline Concerns about memory loss & 23 & $30.3 \%$ & 86 & $50.3 \%$ & 0.005 & 24 & $30.8 \%$ & 82 & $52.9 \%$ & 0.002 \\
\hline
\end{tabular}

n.a.: not applicable

and widowed participants were more likely to self-rate their health as unhealthy compared with those that were married $(\mathrm{OR}=2.47,95 \% \mathrm{Cl} 1.30$ to 4.70$)$. In both countries having more than enough income at the end of the month was associated with a significant lower odds of being unhealthy compared with those without enough income at the end of the month (Portugal: $\mathrm{OR}=0.25,95 \% \mathrm{Cl} 0.10$ to 0.63 ; Poland: $\mathrm{OR}=0.33,95 \% \mathrm{Cl} 0.12$ to 0.88$)$. An increased proportion of the threats to health identified with EASYCare were consistently found in the unhealthy group, however the values obtained differed between the two countries (Table 2).
Associations between the selected threats to health identified with EASYCare and unhealthy self-rated health were calculated after adjusting for age, sex, marital status and income (Table 2). Reported vision problems or using the bath or shower were associated with being unhealthy among the Polish participants. Among the Portuguese participants, the associations were weaker or non-significant. In both countries, having had falls in the last twelve months was not associated with being unhealthy, although an increased proportion of falls was reported by those feeling unhealthy compared to the healthy. An increased proportion of older people reporting feeling out of breath during normal activities 
Table 2 - Associations between threats to health identified with EASYCare and unhealthy self-rated health in two European countries

\begin{tabular}{|c|c|c|c|c|}
\hline \multirow[b]{2}{*}{ Characteristic } & \multicolumn{2}{|c|}{ Portugal } & \multicolumn{2}{|c|}{ Poland } \\
\hline & $\mathrm{OR}^{*}$ & $(95 \% \mathrm{Cl})$ & $\mathrm{OR}^{*}$ & $(95 \% \mathrm{Cl})$ \\
\hline \multicolumn{5}{|l|}{ Difficulties } \\
\hline Seeing & 1.941 & $(1.064,3.541)$ & 3.652 & $(1.802,7.403)$ \\
\hline Hearing & 0.867 & $(0.469,1.601)$ & 1.832 & $(0.920,3.647)$ \\
\hline Using the bath or shower & 1.852 & $(0.801,4.280)$ & 5.054 & $(1.895,13.482)$ \\
\hline Problems with mouth or teeth & 0.935 & $(0.478,1.829)$ & 1.693 & $(0.857,3.344)$ \\
\hline Incontinence of urine & 1.128 & $(0.549,2.315)$ & 2.377 & $(1.269,4.454)$ \\
\hline Falls in the last twelve months & 1.835 & $(0.915,3.682)$ & 1.090 & $(0.570,2.086)$ \\
\hline Get out of breath during normal activities & 3.218 & $(1.625,6.374)$ & 4.419 & $(2.361,8.270)$ \\
\hline $\begin{array}{l}\text { Unable to pursue leisure interests, hobbies, } \\
\text { work and learning activities }\end{array}$ & n.a. & & 3.399 & $(1.765,6.548)$ \\
\hline Feeling lonely & 1.591 & $(0.833,3.039)$ & 2.810 & $(1.444,5.465)$ \\
\hline Trouble sleeping & 0.537 & $(0.281,1.026)$ & 1.788 & $(0.981,3.260)$ \\
\hline Bodily pain & 8.578 & $(4.226,17.414)$ & 2.757 & $(1.415,5.372)$ \\
\hline Being bothered & 1.967 & $(1.025,3.775)$ & 2.727 & $(1.284,5.791)$ \\
\hline Concerns about memory loss & 2.042 & $(1.117,3.734)$ & 2.600 & $(1.415,4.776)$ \\
\hline
\end{tabular}

OR: odds ratio; $\mathrm{Cl}$, confidence interval; n.a., not applicable

* The odds ratios were calculated referenced by the "healthy" group, using logistic regression analysis adjusted for age, sex, marital status and finances; odds ratio > 1 are associated with increased odds of having self-rated health as "unhealthy".

was found among the unhealthy groups. Bodily pain was found in more than eighty percent of older people included in the unhealthy group in both countries, decreasing to $46 \%$ and $63 \%$ in the healthy groups of Portuguese and Polish participants, respectively (Table 1). Portuguese older people with bodily pain had nine-fold increased odds of reporting fair/poor health $(\mathrm{OR}=8.58,95 \% \mathrm{Cl} 4.23$ to 17.41$)$ than those without bodily pain, and among Polish participants, there was an increased odds too (OR $=2.76,95 \% \mathrm{Cl} 1.42$ to 5.37). Mental health (unable to pursue leisure interests, hobbies, work and learning activities, feeling lonely, being bothered and memory loss) was consistently associated with fair or poor self-rated health (Table 2).

\section{DISCUSSION}

This study characterized and compared two European countries, a Central and a Southern country, evaluated with the international EasyCare standard 2010 instrument, providing information about threats to health and well-being among the older population. Similar results were obtained concerning the perceived health and well-being in Portugal and Poland. Although the socio-demographic profile differed, in both countries only about one third of the older persons self-rated their health as healthy. The differences between the two countries included marital status, formal education and finances at the end of the month. In the Polish sample a larger proportion were women (78\% vs $53.8 \%$ ), were single, separated or divorced (24.5\% vs $8.9 \%)$, had formal education between 5 to 12 years ( $80.7 \%$ vs $11.3 \%$ ) and had a surplus of money at the end of the month $(41 \%$ vs $15 \%$ ) while in Portugal, for their part, this study showed that for almost of a quarter of Portuguese persons there wasn't enough money at the end of the month. Bearing in mind that
Portugal is one of the European countries that registered the largest decline in household income since $2009,{ }^{9}$ the results of this study confirmed this trend among Portuguese elders. In Poland the level of education of older people (in terms of upper secondary education) is similar to that of the whole adult population ${ }^{6,15,43}$ while in Portugal the level of education of older persons is much lower than the level of education of the Portuguese adult population. This lower proportion of formal education in older people can influence, for instance, the financial situation and in turn the increase of diseases or risk factors associated. ${ }^{44}$ Nevertheless, the proportion of participants perceiving their health as fair or poor was similar in Portugal and Poland.

Although the strength of the observed associations with self-perception of health differed between countries, the unhealthy perception was consistently associated with indicators of major health threats namely, visual problems, bodily pain, memory loss, feeling bored or lonely and reporting shortness of breath during normal activities. Although there was a significantly higher proportion of people reporting health threats among those perceiving their health as fair or poor, in both groups a considerable proportion of the participants had visual problems and the majority reported feeling lonely, having bodily pain and trouble sleeping. Trouble sleeping and bodily pain are two great threats to health and well-being. Scientific evidence has shown in recent years that pain is associated with sleep problems ${ }^{45}$ which in turn is a threat to balance leading to falls ${ }^{46}$ and decline of independence with impact on health. ${ }^{47}$ Pain was found to be very common in Portugal and Poland, in line with the findings of other studies, highlighting the need to develop strategies to manage pain among the European older population. ${ }^{48}$ 
In this study, around one quarter of the persons reported falls in the last twelve months. This finding concurs with known figures for Europe and USA $(28 \%-35 \%$ of older people over 64 years of age fall each year). ${ }^{26-28,34}$

In Poland, stronger associations were found between the perceived unhealthy status and threats to health, such as visual and hearing impairment, using the bath or shower, urinary incontinence, loneliness, and difficulty in sleeping. These findings may be due to the fact that in the Polish sample there were more women. Being a woman is commonly associated with bladder and bowel dysfunction, and may be partially explained by the specific diseases of women such as gynecological disorders. ${ }^{49}$

Also, loneliness is an important threat to consider. Even among older people who consider themselves healthy a considerable proportion referred this feeling, more than half in Portugal and more than a third in Poland. Considering loneliness an indicator of cognitive decline,,$^{50}$ the results here found should ensure targeted interventions to reduce the risk of those kind of feelings in these populations.

The oral health problems were not associated with the self-perception of being healthy or unhealthy. However, the proportion of people that reported having oral health problems, vision problems and hearing problems are issues that should be considered, in order to prevent future burden.

Although the study has certain limitations, such as a small convenience sample and self-report, it is a crosssectional study of primary health care patients from two European countries using the EASYCare. As such, the results obtained should reflect to some extent the perceived health threats of an aging population in Europe. Another limitation of the study is that the subsamples of Portuguese and Polish participants were previously considered for the validation of EASYCare in both countries. However this is the first time that the full sample including Portugal and Poland was used. Furthermore, in the present study only part of the questions of the EASYCare instrument were considered rather than the full instrument.

EASYCare with a simple personalized language, has the potential to recognize early health threats in a generation with specific challenges posed by ageing. EASYCare can thus also be a tool that can lead to: i) improvement of individual care; ii) reduction of hospital admissions; iii) help in deciding the allocation of resources; iv) help in the creation of sustainable health care.

Current increasing demographic trends of an ageing population are a constant challenge for all European countries, and will have a significant impact on Europe's life in the future. EASYCare provides a way of assessing the social, environmental, economic and personal factors that influence the health of older people. The authors believe that EASYCare will help in the assessment and evaluation of the needs of care of older people in Europe prematurely, so that new solutions can be designed to meet their needs.

The cooperation and coordination in the field of research on health threats on ageing at European level needs to continue in order to help the health professionals and the governments find common denominators to understand, detect, prevent and combat ill-being and diseases early. ${ }^{42}$ Additional studies involving other countries are needed to increase knowledge in relation to those denominators.

\section{CONCLUSION}

The populations studied were from two countries from different regions of Europe with different cultural, social and political contexts. Despite the fact that the Polish and the Portuguese participants had different life histories and have a different socio-demographic profile, the patterns of health threats found were very similar, which implies that targeted strategies can be provided in a comprehensive manner (European) or in a direct manner (in each country).

\section{PROTECTION OF HUMANS AND ANIMALS}

The authors declare that the study was approved by the following ethics committees of Portugal [Ethics Committee of the Central Regional Health Administration (ARS)] and Poland (Ethics Committee of the Poznan University of Medical Sciences).

\section{DATA CONFIDENTIALITY}

The authors declare having followed the protocols in use at their working center regarding patients'data publication. Informed consent was duly obtained from the patient.

\section{CONFLICTS OF INTEREST}

All authors report no conflict of interest.

\section{FUNDING SOURCES}

This article was supported by ERDF (European Regional Development Fund) through the operation POCI-01-0145FEDER-007746 funded by the Programa Operacional Competitividade e Internacionalização - COMPETE2020 and by National Funds through FCT - Fundação para a Ciência e a Tecnologia within CINTESIS, R\&D Unit (reference UID/IC/4255/2013).

\section{REFERENCES}

1. Fuster V. Changing Demographics: A New Approach to Global Health Care Due to the Aging Population. J Am Coll Cardiol. 2017;69:3002-5.

2. Strengthening of palliative care as a component of integrated treatment throughout the life course. J Pain Palliat Care Pharmacother. 2014;28:130-4.

3. Omran AR. The epidemiologic transition: a theory of the epidemiology of population change. 1971. Milbank Q. 2005;83:731-57.

4. Caldwell JC. Population health in transition. Bull World Health Organ.
2001;79:159-60.

5. Rowe JW, Fulmer T, Fried L. Preparing for Better Health and Health Care for an Aging Population. JAMA. 2016;316:1643-4.

6. Sagan A, Panteli D, Borkowski W, Dmowski M, Domanski F, Czyzewski M, et al. Poland health system review. Health Syst Transit. 2011;13:1193.

7. Fundação Francisco Manuel dos Santos - Pordata: Base de Dados Portugal Contemporâneo. População residente com 15 a 64 anos e 65 e 
mais anos: por nível de escolaridade completo mais elevado - Portugal Lisboa2015 [consultado 2016 Set 20]. Disponível em: http://www. pordata.pt/.

8. Oliveira MD, Pinto CG. Health care reform in Portugal: an evaluation of the NHS experience. Health Econ. 2005;14:S203-20.

9. OECD. How's Life 2015: Measuring Well-being, OECD Publishing, Paris. 2015 [consultado 2016 Jul 14]. Disponível em: http://www.oecdilibrary.org/economics/how-s-life-2015_how_life-2015-en.

10. Brandão MP, Sousa L, Philp I, Cardoso MF. Portuguese older people's self-perception of their (in)dependency: a cross-sectional study. J Aging Innovation. 2015;4:3 -17.

11. Moreira C, Bassi AR, Brandão MP, Silva AG. Do patients with chronic neck pain have distorted body image and tactile dysfunction? Eur J Physiother. 2017;19:215-21.

12. Walker W, Porock D, Timmons S. The importance of identity in falls prevention. Nurs Older People. 2011;23:21-6.

13. Reynolds SL, Silverstein M. Observing the onset of disability in older adults. Soc Sci Med. 2003;57:1875-89.

14. Alizad V, Fadayevatan R, Asgari A, Brandão MP, Sousa L, Cheung AC, et al. Global application of use of EASYCare. J Nutr Health Aging. 2013;17(1):75-6.

15. Brandão MP, Gonçalves J, Sá-Couto P, Sousa L. Functional independence of old people with mental disorders: a study in a psychogeriatric unit in Portugal. Rev Port Saude Publica. 2015;33:199206.

16. Melis RJF, van Eijken MIJ, Teerenstra S, van Achterberg T, Parker SG, Borm GF, et al. Multidimensional Geriatric Assessment: Back to the Future A Randomized Study of a Multidisciplinary Program to Intervene on Geriatric Syndromes in Vulnerable Older People Who Live at Home (Dutch EASYcare Study). J Gerontol A Biol Sci Med Sci. 2008;63:28390.

17. Talarska D, Pacholska R, Strugala M, Wieczorowska-Tobis K. Functional assessment of the elderly with the use of EASY-Care Standard 2010 and Comprehensive Geriatric Assessment. Scand J Caring Sci. 2016;30:419-26.

18. Pinto JM, Kern DW, Wroblewski KE, Chen RC, Schumm LP, McClintock MK. Sensory function: insights from Wave 2 of the National Social Life, Health, and Aging Project. J Gerontol B Psychol Sci Soc Sci. 2014;69:S144-53.

19. Raschilas F. Le vieillissement sensoriel. Soins Gerontol. 2006;57:14-5.

20. Kallin K, Lundin-Olsson L, Jensen J, Nyberg L, Gustafson Y. Predisposing and precipitating factors for falls among older people in residential care. Public Health. 2002;116:263-71.

21. Yamada $Y$, Vlachova M, Richter T, Finne-Soveri H, Gindin J, van der Roest $\mathrm{H}$, et al. Prevalence and correlates of hearing and visual impairments in European nursing homes: results from the SHELTER study. J Am Med Dir Assoc. 2014;15:738-43.

22. Cohen-Mansfield J, Shmotkin D, Goldberg S. Loneliness in old age: longitudinal changes and their determinants in an Israeli sample. Int Psychogeriatr. 2009;21:1160-70.

23. Conroy RM, Golden J, Jeffares I, O'Neill D, McGee H. Boredomproneness, loneliness, social engagement and depression and their association with cognitive function in older people: a population study. Psychol Health Med. 2010;15:463-73.

24. Health Quality Ontario. Social isolation in community-dwelling seniors: an evidence-based analysis. Ont Health Technol Assess Ser. 2008;8:149.

25. Tom SE, Adachi JD, Anderson FA, Jr., Boonen S, Chapurlat RD, Compston JE, et al. Frailty and fracture, disability, and falls: a multiple country study from the global longitudinal study of osteoporosis in women. J Am Geriatr Soc. 2013;61:327-34.

26. Kaminska MS, Brodowski J, Karakiewicz B. Fall risk factors in community-dwelling elderly depending on their physical function, cognitive status and symptoms of depression. Int J Environ Res Public Health. 2015;12:3406-16.

27. Lehtola S, Koistinen P, Luukinen H. Falls and injurious falls late in homedwelling life. Arch Gerontol Geriatr. 2006;42:217-24.

28. Lin MR, Hwang HF, Hu MH, Wu HD, Wang YW, Huang FC. Psychometric comparisons of the timed up and go, one-leg stand, functional reach, and Tinetti balance measures in community-dwelling older people. J Am Geriatr Soc. 2004;52:1343-8.

29. Moniz-Pereira V, Carnide F, Machado M, Andre H, Veloso AP. Falls in Portuguese older people: procedures and preliminary results of the study Biomechanics of Locomotion in the Elderly. Acta Reumatol Port. 2012;37:324-32.

30. Cacioppo JT, Hawkley LC, Norman GJ, Berntson GG. Social isolation Ann N Y Acad Sci. 2011;1231:17-22.

31. Ertel KA, Glymour MM, Berkman LF. Effects of social integration on preserving memory function in a nationally representative US elderly population. Am J Public Health. 2008;98:1215-20.

32. Marsden CA, King MV, Fone KC. Influence of social isolation in the rat on serotonergic function and memory--relevance to models of schizophrenia and the role of $5-\mathrm{HT}(6)$ receptors. Neuropharmacology. 2011;61:400-7

33. Winter L, Lawton MP, Casten RJ, Sando RL. The relationship between external events and affect states in older people. Int J Aging Hum Dev. 2000;50:85-96

34. Drageset J, Dysvik E, Espehaug B, Natvig GK, Furnes B. Suffering and mental health among older people living in nursing homes-a mixedmethods study. PeerJ. 2015;3:e1120.

35. Tobis S, Jaracz K, Talarska D, Kropińska S, Zasadzka E, Pawlaczyk M, et al. Validity of the EASYCare Standard 2010 assessment instrument for self-assessment of health, independence, and well-being of older people living at home in Poland. Eur J Ageing. 2017;pp 1-8.

36. Brandao MP, Martins L, Philp I, Cardoso MF. Reliability and validity of the EASYCare-2010 Standard to assess elderly people in Portuguese Primary Health Care. Aten Primaria. 2017.

37. Davis H, Philp I, Ritters K, editors. Easy-Care: Improving the Lives of Older People through Better Assessment and Response to their Health and Care Needs. Social Policy Association Conference: Bigger Societies, Smaller Governments University of Lincoln. Lincoln. United Kingdom. 2011 4-6 July. University of Lincoln. Lincoln, United Kingdom.

38. Martin R, Williams C, O'Neill D. Retrospective analysis of attitudes to ageing in the Economist: apocalyptic demography for opinion formers. BMJ. 2009;339:b4914.

39. Olde-Rikkert MG, Long JF, Philp I. Development and evidence base of a new efficient assessment instrument for international use by nurses in community settings with older people. Int J Nurs Stud. 2013;50:1180-3.

40. Philp I, Newton P, McKee KJ, Dixon S, Rowse G, Bath PA. Geriatric assessment in primary care: formulating best practice. $\mathrm{Br} \mathrm{J}$ Community Nurs. 2001;6:290-5.

41. Philip KE, Alizad V, Oates A, Donkin DB, Pitsillides C, Syddall SP, et al. Development of EASY-Care, for brief standardized assessment of the health and care needs of older people; with latest information about cross-national acceptability. J Am Med Dir Assoc. 2014;15:42-6.

42. Craig C, Chadborn N, Sands G, Tuomainen H, Gladman J. Systematic review of EASY-care needs assessment for community-dwelling older people. Age Ageing. 2015;44:559-65.

43. Tambor M, Pavlova M, Golinowska S, Sowada C, Groot W. Towards a stakeholders' consensus on patient payment policy: the views of healthcare consumers, providers, insurers and policy makers in six Central and Eastern European countries. Health Expect. 2015;18:475-88.

44. Coady SA, Johnson NJ, Hakes JK, Sorlie PD. Individual education, area income, and mortality and recurrence of myocardial infarction in a Medicare cohort: the National Longitudinal Mortality Study. BMC Public Health. 2014;14:705

45. Chen Q, Hayman LL, Shmerling RH, Bean JF, Leveille SG. Characteristics of chronic pain associated with sleep difficulty in older adults: the Maintenance of Balance, Independent Living, Intellect, and Zest in the Elderly (MOBILIZE) Boston study. J Am Geriatr Soc. 2011;59:1385-92.

46. Helbig AK, Doring A, Heier M, Emeny RT, Zimmermann AK, Autenrieth $\mathrm{CS}$, et al. Association between sleep disturbances and falls among the elderly: results from the German Cooperative Health Research in the Region of Augsburg-Age study. Sleep Med. 2013;14:1356-63.

47. Cochen V, Arbus C, Soto ME, Villars H, Tiberge M, Montemayor T, et al. Sleep disorders and their impacts on healthy, dependent, and frail older adults. J Nutr Health Aging. 2009;13:322-9.

48. Karttunen NM, Turunen J, Ahonen R, Hartikainen S. More attention to pain management in community-dwelling older persons with chronic musculoskeletal pain. Age Ageing. 2014;43:845-50.

49. NIH state-of-the-science conference statement on prevention of fecal and urinary incontinence in adults. NIH Consens State Sci Statements. 2007;24:1-37.

50. Gow AJ, Mortensen EL. Social resources and cognitive ageing across 30 years: the Glostrup 1914 Cohort. Age Ageing. 2016. 